\title{
Az észlelt társas támogatás összefüggéseinek vizsgálati lehetőségei a PRISM-D rajzteszt segítségével kórházi kezelés alatt álló súlyos betegek körében
}

\author{
Sándor Zita ${ }^{1,2}$ - Látos Melinda dr., ${ }^{3,4}$ Csabai Márta dr. ${ }^{3}$ \\ 'Szegedi Tudományegyetem, Általános Orvostudományi Kar, Klinikai Orvostudományok Doktori Iskola, Szeged \\ ${ }^{2}$ Gál Ferenc Főiskola, Egészség és Szociális Tudományi Kar, Gyula \\ ${ }^{3}$ Szegedi Tudományegyetem, Általános Orvostudományi Kar, Pszichológiai Intézet, Szeged \\ ${ }^{4}$ Szegedi Tudományegyetem, Általános Orvostudományi Kar, Sebészeti Klinika, Szeged
}

Bevezetés: Kórházi betegek körében a betegség okozta változások miatt a társas kapcsolatok átrendeződhetnek, erősödhetnek, de akár gyengülhetnek is. Ezen változások mérése, a szubjektíve megélt társas támogatás mértékének, elérhetőségének vagy akár az észlelt izolációnak a kimutatása fontos feladat, ugyanis ezen dimenziók összefüggnek a gyógyulási mutatókkal.

Célkitüzés: A kutatás célja annak bemutatása, hogy az általunk fejlesztett PRISM-D rajzteszt hogyan alkalmazható az észlelt társas támogatás mérésére. További célkitűzés a teszten mért társas támogatás mutatóinak és a depresszió-, valamint a szorongásszint közötti kapcsolatnak a vizsgálata súlyos betegek esetében.

Módszer: 194 súlyos, kórházi kezelés alatt álló beteg (daganatos, mútéti beavatkozást igénylő gyomor-bél rendszeri betegségben és krónikus veseelégtelenségben szenvedő betegek) esetében a PRISM-D rajzteszt, a STAI- és BDItesztek felvétele kórházi osztályokon.

Eredmények: A vizsgálati személyek többsége megjelenítette a rajzteszten a társas támogatást $(95,7 \%)$, jelentős hányaduk több körrel $(64,0 \%)$ és nagyobbnak, mint a betegséget szimbolizáló kör (71,2\%). Azok a személyek, akik nem jelenítettek meg egyetlen társas támogató személyt sem, szignifikánsan magasabb szorongásszintet éltek meg (STAI-S: $\mathrm{p}=0,040, \mathrm{df}=181 ;$ STAI-T: $\mathrm{p}=0,005, \mathrm{df}=153)$. A térbeli elhelyezkedést tekintve azok a betegek, akik az Ént és a betegséget szimbolizáló kör közé helyezték el a társas támogatást, alacsonyabb szintû szorongást és depresszív tüneteket éltek meg, mint akik a betegséget rajzolták közelebb, a társas támogatást távolabb (STAI-S: $\mathrm{p}=0,016$, $\mathrm{df}=91 ; \mathrm{BDI}: \mathrm{p}=0,027, \mathrm{df}=142)$.

Következtetés: Eredményeink szerint a PRISM-D rajzteszt alkalmas az észlelt társas támogatás vizsgálatára, az Énhez és a betegséghez viszonyított szubjektív jelentőségének és észlelt közelségének mérésére, továbbá az észlelt szociális izoláció detektálására. Gyors, egyszerű mérőeszközként nagymértékben segítheti kórházi osztályokon a szűrést és a terápiás munkát.

Orv Hetil. 2020; 161(39): 1688-1696.

Kulcsszavak: társas támogatás, pszichológiai teszt, rajzolás

\section{Using PRISM-D drawing test for the examination of associations of perceived social support among inpatients with chronic medical conditions}

\footnotetext{
Introduction: Changes caused by illness can lead to a reorganization, either strengthening or weakening social relationships among hospitalized patients. Measuring these changes, and the detection of the extent and availability of perceived social support or even of the perceived isolation is an important task, as these dimensions are related to disease outcomes.

Aim: The aim of the research is to demonstrate the applicability of the PRISM-D drawing test developed by us to measure perceived social support. A further objective is to examine the relationship between test social support measures and depression and anxiety levels of severely ill patients.

Method: The PRISM-D drawing test, STAI and BDI tests were used among 194 patients (with tumor, gastrointestinal illness requiring surgery and chronic renal failure) in hospital wards.
} 
Results: The most test subjects drew circles representing social support on the test $(95.7 \%)$; most of them drew more circles $(64.0 \%)$ and of larger size $(71.2 \%)$ than the circle symbolizing the illness. Individuals who did not display anyone as source of social support experienced significantly higher levels of anxiety (STAI-S: $\mathrm{p}=0.040, \mathrm{df}=181$; STAI-T: $\mathrm{p}=0.005, \mathrm{df}=153$ ). In terms of spatial location, patients who placed social support between the Self and the circle symbolizing illness experienced lower levels of anxiety and depressive symptoms than those drawing the illness closer and social support farther (STAI-S: $\mathrm{p}=0.016, \mathrm{df}=91$; BDI: $\mathrm{p}=0.027, \mathrm{df}=142$ ).

Conclusion: According to our results, the PRISM-D drawing test is suitable for examining perceived social support, measuring its relative significance and perceived proximity to the Self and the illness, and detecting perceived social isolation. As a quick, simple measurement tool, it can greatly help screening and therapeutic work in hospital wards.

Keywords: social support, psychological test, drawing

Sándor Z, Látos M, Csabai M. [Using PRISM-D drawing test for the examination of associations of perceived social support among inpatients with chronic medical conditions]. Orv Hetil. 2020; 161(39): 1688-1696.

(Beérkezett: 2020. április 2.; elfogadva: 2020. április 22.)

\section{Rövidítések}

BDI = (Beck Depression Inventory) Beck Depresszió Kérdőív; $\mathrm{df}=$ szabadsági fok; FACT $=$ (functional assessment of cancer therapy) a rákterápia funkcionális értékelése; HIV = (human immunodeficiency virus) emberi immunhiányt elóidéző vírus; IPM = (illness perception measure $)$ a betegségpercepciót méró érték; $M$ = átlag; PRISM = Pictorial Representations of Illness and Self Measure; PRISM-D = (drawing version of PRISM) a PRISM rajztesztverziója; $\mathrm{SD}=$ (standard deviáció) szórás; SIS $=($ Self-illness separation $)$ Én-betegség távolság; STAI = (State-Trait Anxiety Inventory) Spielberger-féle Vonás- és Állapotszorongás Kérdőív; STAI-S = a STAI 'állapotszorongás' alskálája; STAI-T = a STAI 'vonásszorongás' alskálája

A társas támogatás nagyon fontos tényező súlyos testi betegséggel való megküzdés során. Egy betegség ugyanis számos testi, lelki és szociális kihívás elé állítja az egyént, melyek próbára tehetik a személy teherbíró képességét. Számtalan tanulmány igazolta, hogy az ilyen nehéz élethelyzetekben a jól múködő társas támogatás, azaz a szignifikáns/jelentős mások (például család, barátok, ismerősök) által biztosított pszichoszociális erőforrások [1] jelenléte számos pozitív következménnyel jár [2].

Vizsgálati eredmények alapján a magasabb szintű társas támogatást észlelő személyek lelkileg jobban viselik a betegséggel járó változásokat, mely összefüggést többek között szívbetegek, diabeteses, HIV-fertőzött, daganatos és rheumatoid arthritisben szenvedő betegek esetében is kimutatták [3-7]. Más kutatási eredmények arra hívják fel a figyelmet, hogy a magasabb szintü társas támogatás mútét utáni alacsonyabb fájdalommal és jobb kezeléskimenettel jár együtt súlyos betegek esetében [8, 9], általánosságban pedig elmondható, hogy pozitívan befolyásolja a morbiditási, mortalitási és életminőségmutatókat krónikus betegséggel küzdő személyeknél [10].
A társas támogatás általános egészségre gyakorolt pozitív hatásának hatásmechanizmusára vonatkozóan több elmélet született. Egyrészt a társas támogatás direkt fiziológiai hatása révén kedvezően befolyásolja a cardiovascularis, endokrin és immunrendszert, ezáltal jótékony hatást gyakorolva a gyógyulási folyamatra [11]. A napjainkban népszerú stresszpufferelmélet szerint (Theory on Stress Buffering) a társas támogatás azáltal fejti ki pozitív hatását, hogy képes a negatív stressz hatásait felfogni, pufferelni, és a stressz-szint csökkentése révén járul hozzá a pozitív egészségi kimenetelekhez [12]. Továbbá közvetett hatásként a társas támogatás pozitív hatással bír a mentális egészségre, például csökkenti a pszichológiai distressz és a depresszió kialakulásának kockázatát [13-16]. A depresszív tünetekre gyakorolt kedvező hatásának hátterében egyrészt direkt hatásról beszélhetünk, a társas támogató személyek érzelmi és funkcionális támogatásának biztosítása révén, másrészt észlelt erőforrásként hat azáltal, hogy a személyek nem érzik izoláltnak és magányosnak magukat $[17,18]$.

Mindezek mellett a megfelelő társas támogatás segítségével a beteg információt, segítséget és érzelmi támogatást kaphat, ami hozzájárulhat a betegség elfogadásához és a megfelelő megküzdéshez [11, 19]. Az, ahogyan a családtagok reagálnak a betegségre, valamint a betegség kezelésébe való bevonódásuk, részvételük nagymértékben befolyásolhatja a betegek egészségvédő viselkedését és így a betegség kimenetelét is [20,21]. Ezek mellett a társas támogató személyek erősíthetik a betegben azt az érzést, hogy fontos számukra, és érdemes meggyógyulnia [22], ami célt adhat a betegnek.

Fontos figyelembe venni, hogy egy súlyos betegség és annak következményei átstrukturálhatják a társas kapcsolatokat, erösíthetik, de akár gyengíthetik is azokat [23]. A társas kapcsolatok számára kihívást jelent a betegség diagnózisa, kezelése és lefolyása [24, 25]. Számos tanulmány kimutatta, hogy a krónikus betegséggel élő személyeknek kevesebb társas kapcsolatuk van, mint az egészséges személyeknek [26-28]. Vizsgálatok szerint a 
leginkább a barátokkal és az ismerősökkel való kapcsolatok korlátozódnak, a partnerrel és gyermekkel való kapcsolatra azonban többnyire nem gyakorol a betegség ilyen negatív hatást, sőt ezek a kapcsolatok akár fokozódhatnak, erősödhetnek [29].

Sokszor azonban a betegség kezelése vezet ahhoz, hogy akár átmenetileg, akár tartósan a betegek szociális izolációt, magányosságot élnek meg, ugyanis gyakran vagy a betegség fizikai tünetei, vagy a kezelés miatt korlátozódik a családdal és a barátokkal való kapcsolattartás (például intenzív osztályos ellátás, karantén). A betegek sok esetben kénytelenek egyedül szembenézni a betegségük okozta teherrel. A megélt szociális izoláció, magányosság azonban nem kedvező, vizsgálati eredmények szerint ugyanis negatív egészségkimenetelekkel jár együtt [30].

Szem előtt kell azonban tartani azt, hogy az izoláció megélése nagyon szubjektív, csakúgy, mint az, hogy a személy milyen mértékű és jellegû támogatást vár el a társas közegtől, ráadásul ezek a betegséglefolyás során akár jelentősen változhatnak. Egyedi az is, hogy a személy a potenciálisan rendelkezésre álló támogató kapcsolatokat és az objektíve érkező társas támogatási formákat miként észleli és értékeli. A támogató tényezők egyéni sajátosságokkal bíró érzékelése [2] az ún. észlelt társas támogatás, mely a személyek egyedi észlelési, értékelési és memóriafolyamatainak következményeként jön létre. Kutatási eredmények alapján ez a szubjektív kép jár együtt a kedvező egészségkimenetelekkel, és nem az objektíve rendelkezésre álló kapcsolatok száma [31, 32]. Éppen ezért a társas támogatás vizsgálata során fontos ezt a dimenziót vizsgálni.

A társas támogatás tehát kiemelten fontos tényező a gyógyulás szempontjából, ugyanakkor a jelenség komplexitása miatt a mérése nem könnyú. A legtöbb mérőeszköz önkitöltős, papír-ceruza teszt, melyek nem teszik lehetôvé a társas támogató tényezők szubjektív fontosságának, a személyekhez való tudattalan viszonyulásuknak a feltárását. Ezen dimenziók vizsgálata azonban lényeges információkkal járulhat hozzá a személy társas kapcsolatainak feltérképezéséhez, valamint az egyénre szabott pszichés intervenció előkészítéséhez.

Az intervenciós kutatások eredményei szerint ugyanis a társas támogatás fejlesztésére, javítására irányuló pszichoszociális intervenciók potenciálisan hozzájárulhatnak a betegek pozitívabb egészségi állapotához [33, 34]. Ahhoz azonban, hogy az intervenció szükségességére egyáltalán fény derüljön, nélkülözhetetlen a beteg kapcsolataihoz való szubjektív viszonyulásának feltárása, illetve az esetlegesen megjelenő észlelt izoláció detektálása. Érdemes figyelembe venni továbbá azt is, hogy a hagyományos papír-ceruza tesztek relatíve nagy energiaráfordítást és jól múködő verbális készségeket igényelnek a páciensektől, melyek bizonyos gyógyítási helyzetekben nem vagy csak korlátozottan állnak rendelkezésre.

$\mathrm{Az}$ általunk fejlesztett PRISM-D rajzteszt egy olyan nonverbális eszköz, mely lehetővé teszi a betegséggel küzdő személyek aktuális életterében jelen levő fontos tényezók feltárását [35-37]. Az eredeti PRISM-tesztverzió egy olyan vizuális méróeszköz, mely a betegség okozta tehernek, a betegség Énre gyakorolt hatásának és a betegségpercepciónak a feltárását teszi lehetővé [38, 39]. A teszt módosított változatainak segítségével az élettér egyéb fontos tényezői is feltárhatók (PRISM+ tesztek) [40], az általunk fejlesztett rajztesztverziója (PRISM-D) pedig lehetőséget ad a betegséggel küzdő személy életterére vonatkozó szubjektív reprezentációk differenciáltabb mérésére [36]. A rajzolás, mint szabad eszköz, projektív jellege miatt ugyanis alkalmas a tudattalan tényezők és viszonyulások feltárására.

Az eredeti PRISM-tesztet eredményesen használták a társas támogatás mérésére, korábbi vizsgálatokban szignifikáns összefüggést találtak a PRISM-en mért észlelt társas támogatás és a FACT-skála 'társas támogatás' alskálája között. Továbbá az észlelt társas támogatás és a fájdalom kapcsolata mindkét mérőeszköz (a PRISM-en megjelenített 'társas támogatás' és a FACT-féle 'társas támogatás’ alskála) esetében hasonló eredményeket hozott [41]. Véleményünk szerint a rajztesztverzió segítségével az eredeti teszthez képest további hasznos információk nyerhetók.

Tanulmányunk célja megvizsgálni, hogy a PRISM-D teszt alkalmas-e az észlelt társas támogatás differenciált mérésére, az észlelt szociális izoláció kiszúrésére, valamint a társas támogatás szubjektíve megélt fontosságának vizsgálatára szomatikus betegséggel küzdő személyek esetében. További célunk a teszten megjelenített társas támogatás betegségpercepcióval, depresszió-, illetve szorongásszinttel való összefüggésének megvizsgálása különböző kórházi kezelések alatt álló súlyos testi betegek esetében.

\section{Módszer}

\section{Résztvevők és a vizsgálat körülményei}

A vizsgálatban 194, különböző súlyos szomatikus betegséggel küzdő személy vett részt. A vizsgálati személyek 56,2\%-a daganatos beteg, 13\%-a mütéti beavatkozást igénylő gyomor-bél rendszeri beteg, 30,8\%-a pedig krónikus veseelégtelenségben szenvedő beteg volt. A vizsgálati személyek mindegyike kezelés alatt állt az adatfelvétel ideje alatt.

A betegek átlagéletkora 52,77 év volt ( szórás = 14,89). A legfiatalabb résztvevő 14, a legidősebb 79 éves volt. A megkérdezettek 31\%-a férfi, 68,6\%-a nő volt.

Az adatokat a Szent-Györgyi Albert Klinikai Központban, az Országos Onkológiai Intézetben és a Békés Megyei Központi Kórházban gyüjtöttük. Az adatgyújtés a fenti intézmények támogató hozzájárulásával zajlott a vizsgálati személyek önkéntes beleegyezésével, írásos engedélyével. 


\section{Mérôeszközök}

\section{PRISM-D teszt}

A rajzteszten a vizsgálati személyek egy A/4-es fehér lapra rajzolnak be tetszóleges számú, méretű köröket, melyek a betegségüket és az életterük azon tényezőit szimbolizálják, amelyek aktuálisan fontosak számukra [35-37]. A tesztfelvételi lap jobb alsó sarkában egy $7 \mathrm{~cm}$ átmérőjü, Ént szimbolizáló kör van előre nyomtatva. A teszt első részében a páciensek piros filctollal rajzolják be a betegségüket. Az eredeti teszthez hasonlóan az Én és a betegség távolságának kiszámításával (SIS) mérhető a betegségteher, valamint a 'betegség' kör területének kiszámításával mérhető a betegségpercepció (IPM) [38, 39].

A teszt második részében a vizsgálati személyeknek lehetőségük van szabadon berajzolni az életterük egyéb, számukra aktuálisan fontos tényezőit tetszőleges méretü, színű és elhelyezkedésű körök segítségével. A berajzolt körök jelentését a vizsgálatvezető egy erre szolgáló adatlapon jegyzi fel. A válaszokat az elemzés során jelentéskategóriák alapján lehet csoportosítani. Az utóteszt részben a vizsgálati személyektől megkérdeztük, hogy mit jelentenek számukra azok a tényezők, amelyeket berajzoltak. Ezeket a válaszokat szó szerint rögzíti a vizsgálatvezető. Az így nyert kvalitatív adatok többféle szempont alapján elemezhetők.

Korábbi vizsgálati adataink alapján a teszt második részében megjelenített tényezők közül a leggyakoribbak a társas támogatás kategóriájába sorolható válaszok [36]. A jelen vizsgálatban a szabadon megjelenített körök közül csupán azokat a köröket vizsgáltuk, amelyek jelentéstartalmuk alapján egyértelmúen a társas támogatás kategóriájába voltak sorolhatók (például partner, családtag, barát, ismerős, kolléga, szomszéd), és amelyekkel kapcsolatban az utóteszt válaszai alapján is megerősítést nyert, hogy érzelmi és/vagy instrumentális támaszt jelentenek a személyek számára. A válaszok kategorizálása két független kódoló bevonásával történt, melynek során kiemelt figyelmet fordítottunk a társas támogatás jelentéstartalmainak egyértelmú meghatározására.

Az elemzés során mértük az Én és a társastámogatás távolságot, illetve amennyiben a személy több körrel ábrázolta a társas támogatás tagjait, a legközelebb ábrázolt társas támogató tényezőnek az Éntől való távolságát. Ezen mutatók az észlelt társas támogatás közelségére, elérhetőségére utalhatnak. A teszten mérhetővé válik a megjelenített társas támogató tényezők mérete, terület $\left(\mathrm{cm}^{2}\right)$ is, mely az észlelt társas támogatás nagyságát szimbolizálhatja. Továbbá mérhető a társas támogatás és a betegség viszonya, kapcsolata, egymáshoz viszonyított méretük, elhelyezkedésük. A tesztet, valamint a mért mutatókat szemlélteti az 1 . ábra.

\section{STAI}

A betegek szorongásszintjének mérésére a Spielbergerféle Vonás- és Állapotszorongás Kérdőívet (STAI) alkal-

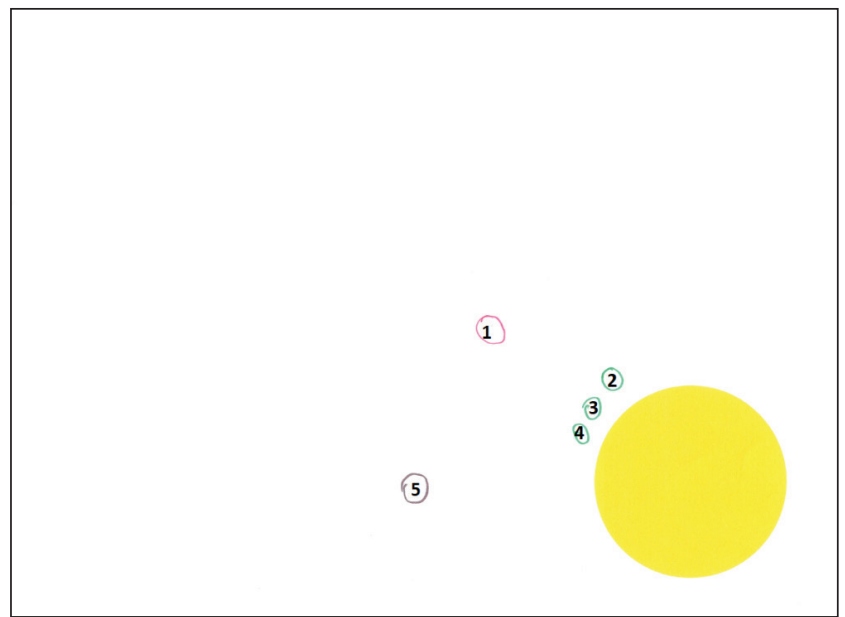

1. ábra

Egy 57 éves, rosszindulatú emlőtumorral kezelt nő PRISM-D tesztje. A teszten az előre nyomtatott sárga kör az Ént szimbolizálja. Kérésünkre az elsőként berajzolt kör a betegséget szimbolizálja, mely az ábrán 1-es számmal lett jelezve. A szabadon berajzolt körök jelentései a következők: 2 = férj, 3 = gyerekek, 4 = unoka, 5 = hobbi, kertészkedés. A 2., 3. és 4 . kör esetében az utótesztben „lelki támasz” jelentést fogalmazott meg, így a kódolásnál a társas támogatás kategóriába soroltuk. A társas támogatást szimbolizáló körök esetében kiszámoltuk az Énhez legközelebb rajzolt támogató tényezők Éntől való távolságát, az összes támogató tényező Éntől való átlagtávolságát, valamint a társas támogató tényezők összterületét. A betegséget szimbolizáló kör esetében kiszámoltuk az Én-betegség távolságot (SIS), valamint a betegség területét (IPM)

IPM = a betegségpercepciót mérő érték; PRISM-D = Pictorial Representations of Illness and Self Measure rajztesztverziója; SIS = Én-betegség távolság

maztuk [42, 43]. A mérőeszköz lehetővé teszi az ún. 'vonásszorongás', vagyis a személyre jellemző általános szorongásszint mérését (STAI-T), valamint az aktuálisan megélt, ún. 'állapotszorongás' (STAI-S) vizsgálatát. Mindkét alskála 20 itemből áll. A válaszokat 1-től 4-ig kell értékelni, így a skálák összpontszáma 20 és 80 közötti értéket vehet fel, amelynél a magasabb pontszám fokozott szorongásos tünetek jelenlétére utal. A kérdőív reliabilitása megfelelő (Cronbach-alfa $=0,77$ ).

\section{BDI}

A páciensek depressziószintjét a Beck-féle Depresszió Kérdőív 21 itemes változatával mértük fel [44-46]. A kérdőívben minden kérdéscsoportnál 4 állítás közül kell eldönteni a vizsgálati személynek, hogy melyik volt jellemző rá az elmúlt hetekben, napokban. A kiértékeléskor a válaszokat 0 -tól 3-ig pontozzuk, így a teljes skála összpontszáma 0 és 84 közötti értéket vehet fel, amelynél a magasabb érték fokozottabb depresszív tünetek jelenlétére utal. A skála belső érvényessége megfelelő.

\section{Adatelemzés}

A statisztikai elemzést az SPSS 21-es verziójának (IBM, Armonk, NY, USA) használatával készítettük. A leíró statisztikák ismertetéséhez átlagértékek, szórásértékek és 
válaszmegoszlások kerültek kiszámításra. A társas támogatás és a hangulati változók kapcsolatának vizsgálata során Student-féle t-tesztet alkalmaztunk.

\section{Eredmények}

\section{Az észlelt társas támogatás megjelenitése}

A PRISM-D teszten a résztvevők 95,7\%-a jelenítette meg a családját vagy annak bizonyos tagját, tagjait. Csupán 4,3\%-uk nem jelenített meg családtagot, sem egyéb társas támogató személyt a PRISM-en, ami az aktuálisan észlelt szociális izolációra utalhat. A betegek 72,7\%-a jelenített meg a családon túl egyéb társas támogató személyeket, például barátokat, kollégákat, szomszédokat. A betegek 36\%-a egy körrel ábrázolta a társas támogatást, 64\%-uk viszont több kör berajzolásával jelenítette meg a számára fontos tényezőket.

A megjelenített társas támogatás összterülete 36,99 $\mathrm{cm}^{2}$ volt $(\mathrm{SD}=52,93)$, mely minimálisan kisebb, mint a teszten megjelenített, Ént szimbolizáló kör területe $\left(38,48 \mathrm{~cm}^{2}\right)$, és nagyobb, mint a vizsgálati személyek által megjelenített betegség területének átlaga $(M=16,29$ $\left.\mathrm{cm}^{2}, \mathrm{SD}=33,11\right)$. Bár ez utóbbi eredmény arra utal, hogy a vizsgálati személyek átlagosan kisebbnek érezték a betegségük terhét és nagyobbnak a társas támogatást, a nagy szórásértékek nagy egyéni változatosságot jeleznek.

A megjelenített társas támogatás Éntôl való távolsága átlagosan $11,10 \mathrm{~cm}$ volt $(\mathrm{SD}=5,8)$. Az Én-betegség átlagtávolsághoz képest $(\mathrm{M}=11,59 \mathrm{~cm}, \mathrm{SD}=7,77) \mathrm{el}$ mondható, hogy a résztvevők közel azonos távolságra jelenítették meg a betegséget, mint általánosságban a társas támogatást. A nagy szórásértékek azonban nagy egyéni változatosságra utalnak. A megkérdezettek

1. táblázat | A PRISM-D teszten megjelenített betegséget és társas támo gatást szimbolizáló körökkel kapcsolatos leíró statisztikák. A PRISM-D teszten megjelenített, betegséget és társas támogatást szimbolizáló körök ábrázolásának gyakorisága, valamint a fenti tényezőknek az Ént szimbolizáló körtől való távolsága és mérete

\begin{tabular}{|c|c|c|c|c|}
\hline & & $\begin{array}{l}\text { Ábrázolta-e? } \\
(\%)\end{array}$ & $\begin{array}{l}\text { Az Éntől } \\
\text { való távolság }\end{array}$ & Mérete \\
\hline Betegség & & $100 \%$ & $\begin{array}{l}M=11,59 \\
(S D=7,77)\end{array}$ & $\begin{array}{l}M=16,29 \\
(S D=33,11)\end{array}$ \\
\hline \multirow{2}{*}{$\begin{array}{l}\text { Társas } \\
\text { támogatás }\end{array}$} & $\begin{array}{l}\text { A } \\
\text { legközelebb } \\
\text { rajzolt } \\
\text { társas } \\
\text { támogató } \\
\text { tényezók } \\
\end{array}$ & \multirow[t]{2}{*}{$95,7 \%$} & $\begin{array}{l}M=9,15 \\
(S D=5,4)\end{array}$ & \multirow{2}{*}{$\begin{array}{c}M=36,99 \\
-(S D=52,93)\end{array}$} \\
\hline & $\begin{array}{l}\text { Az összes } \\
\text { ábrázolt } \\
\text { társas } \\
\text { támogató } \\
\text { tényező }\end{array}$ & & $\begin{array}{l}M=11,10 \\
(S D=5,8)\end{array}$ & \\
\hline
\end{tabular}

M = átlag; PRISM-D = Pictorial Representations of Illness and Self Measure rajztesztverziója; $\mathrm{SD}$ = szórás 43,2\%-a rajzolta az Énhez a betegséget közelebb, a társas támogatást pedig távolabb, ami utalhat arra, hogy a betegség okozta szenvedés, teher jelentősebb, mint a társak által nyújtott támogatás. 56,8\%-uknál azonban a társas támogatás található közelebb az Énhez, a betegség távolabb.

A teszten megjelenített, a betegséghez és a társas támogató tényezőkhöz kapcsolódó leíró statisztikák az 1 . táblázatban láthatók.

\section{A megjelenitett társas támogatás, a betegség, a depresszió- és szorongásszint kapcsolata}

Azok a személyek, akik nem jelenítették meg a PRISM$\mathrm{D}$ teszten a társas támogatást, szignifikánsan nagyobb mértékü állapotszorongást éltek meg $(\mathrm{M}=53,14, \mathrm{SD}=$ 15,11), mint azok a személyek, akik feltüntették bármekkora méretben a társas támogató terük tagját/tagjait $(\mathrm{M}=42,34, \mathrm{SD}=13,52)(\mathrm{t}$-próba, $\mathrm{p}=0,040, \mathrm{df}=181)$. Továbbá azok a betegek, akik nem jelenítették meg a társas támogató tér tagjait a teszten, szignifikánsan magasabb vonásszorongás-értékkel rendelkeztek $(M=50,33$, $\mathrm{SD}=15,37)$, mint akik felrajzolták a társas támogatás valamely tagjait $(\mathrm{M}=37,85, \mathrm{SD}=10,35)$ ( $\mathrm{t}$-próba, $\mathrm{p}=$ $0,005, \mathrm{df}=153)$. Az eredmények alapján azok a személyek, akik aktuálisan nem tartották fontosnak életterükben megjeleníteni a társas támogató tér valamely tagjait (akár észlelt, akár valós hiány vagy másra fókuszáló figyelem), nagyobb szorongást tapasztaltak. A megjelenített tényezők területe, illetve a társas támogatás kategóriába sorolható körök száma azonban nem áll szignifikáns kapcsolatban a szorongásszinttel (minden p>0,05) (2. táblázat).

A társas támogatás Éntől való abszolút távolsága szignifikánsan összefügg az IPM-mel, azonban nem függ össze a depresszió- és szorongásszinttel. A t-próba eredményei alapján azok a személyek, akik az Énhez legközelebb eső, társas támogatást szimbolizáló kört az Énhez közelebb jelenítették meg, szignifikánsan kisebbnek jele-

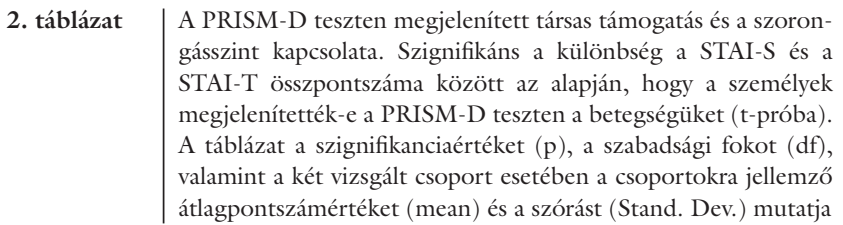

\begin{tabular}{llll}
\hline & Szignifikanciaszint & $\begin{array}{l}\text { Megjelenített } \\
\text { társas támogatást }\end{array}$ & $\begin{array}{l}\text { Nem jelenített meg } \\
\text { társas támogatást }\end{array}$ \\
\cline { 2 - 4 } & $\mathrm{p}(\mathrm{df})$ & Átlag (szórás) & Átlag (szórás) \\
\hline STAI-S & $0,040(181)$ & $42,34(13,52)$ & $53,14(15,11)$ \\
\hline STAI-T & $0,005(153)$ & $37,85(10,35)$ & $50,33(15,37)$ \\
\hline
\end{tabular}

df = szabadsági fok; $\mathrm{M}$ = átlag; $\mathrm{p}=$ szignifikanciaérték; PRISM-D = Pictorial Representations of Illness and Self Measure rajztesztverziója; SD = szórás; STAI-S = a Spielberger-féle Vonás- és Állapotszorongás Kérdőív 'állapotszorongás' alskálája; STAI-T = a Spielberger-féle Vonás- és Állapotszorongás Kérdőív 'vonásszorongás' alskálája 
nítették meg a betegségüket $(M=9,086, S D=12,28)$, mint azok, akik a legközelebbi társas támogató személyt távolabbra rajzolták $(\mathrm{M}=22,39, \mathrm{SD}=49,50)(\mathrm{p}=$ $0,047, \mathrm{df}=72,82)$. Hasonló összefüggést találtunk a megjelenített összes társas támogató tényező Éntől való átlagtávolságával kapcsolatban, bár ez esetben az összefüggés csupán tendenciaszintű volt $(\mathrm{p}=0,068)$. A fenti eredmények arra utalnak, hogy azok a személyek, akik a társas támogatást közelebb érezték magukhoz, szorosabb kapcsolatot/kapcsolatokat éltek meg, kevéssé érezték jelentősnek a betegségüket, ugyanis az IPM a nemzetközi szakirodalom alapján a betegség szubjektív megélésére és fontosságára enged következtetni [39]. Azok a személyek azonban, akik kevéssé érezték magukhoz közel a társas támogatást, feltehetőleg nagyobb jelentőséget tulajdonítottak a betegségüknek, és az vélhetően nagyobb terhet jelentett számukra.

A társas támogatás Éntől mért abszolút távolságán túl fontos vizsgálni a társas támogatásnak a betegség viszonylatában mért relatív távolságát is, a társas támogatás és a betegség egymáshoz viszonyított helyzetét. Eredményeink szerint ugyanis azok a személyek, akik a betegséget közelebb rajzolták az Énhez, a társas támogatást pedig messzebbre, szignifikánsan magasabb depresszióértéket mutattak $(M=9,47, S D=7,08)$, mint akik a társas támogatást rajzolták az Énhez közelebb, a betegséget pedig távolabb $(\mathrm{M}=7,60, \mathrm{SD}=6,80)(\mathrm{p}=0,016$, $\mathrm{df}=91)$. Hasonló eredményt kaptunk az állapotszorongás-érték kapcsán $(\mathrm{p}=0,027, \mathrm{df}=142)$. Azok, akik a társas támogatást távolabb, a betegséget közelebb rajzolták az Énhez, a STAI-S skálán 45,07 pontot kaptak $(S D=13,99)$, akik viszont a társas támogatást rajzolták közelebb, átlagosan 41,07 pontot kaptak $(S D=12,85)$. (Az adatelemzéskor a társas támogatás kategóriájába so- rolt körök közül az Ént szimbolizáló körhöz legközelebb eső kör Éntől való távolságát vettük alapul.) A fenti összefüggést demonstrálja a 2. ábra.

\section{Megbeszélés}

Kutatásunk fő célja a PRISM-D rajzteszt társas támogatás felmérésére való alkalmazhatóságának bemutatása volt. 194, súlyos kórházi fekvő beteg tesztjeit elemezve elmondható, hogy a mérôeszköz széles körú információt nyújt a páciensek szubjektíve megélt, észlelt társas támogató hálójával kapcsolatban. Mindezt egy olyan vizuális technika segítségével, mely alacsony eszközigénye, könynyen érthetősége és gyors alkalmazása miatt jól illeszkedik a klinikai környezethez [35-37]. A teszt lehetőséget ad a szakember számára akár egy viszonylag gyors elemzésre, hiszen ránézésre látható a páciens számára aktuálisan észlelt szociális háló, annak a betegséghez és az Énhez viszonyított mérete, elhelyezkedése. A rajzteszten megjelenített körök jelentését felmérő utóteszt mint kvalitatív technika pedig további információt nyújthat. A válaszokból felmérhető, hogy az aktuális élettérben megjelenített személyek mit jelentenek a páciens számára, érzelmi és/vagy instrumentális támogatást vagy éppen terhet, akadályt.

Eredményeink szerint a társas támogató tér tagjainak észlelt közelsége összefügg a betegségpercepcióval, azok a személyek ugyanis, akik a társas támogatást közelebb rajzolták az Énjükhöz, szignifikánsan kisebbre rajzolták a betegségüket (a teszten a betegség mérete a betegségpercepcióra utal). Ez az eredmény arra enged következtetni, hogy a társas támogatást önmagukhoz közelebb érzékelő páciensek kedvezőbb betegségpercepcióval rendelkeztek, mint azok a személyek, akik aktuálisan nem
A/ A társas támogatás távolabb, a betegség közelebb az Énhez

SIS: $M=6,14(S D=6,20)$, Énhez legközelebbi társas támogatás Éntôl való távolsága: $M=11,21(S D=11,15)$, BDI: $M=9,47(S D=7,08)$, STAI-S: $M=45,07(S D=13,99$
B / A társas támogatás közelebb, a betegség távolabb az Énhez képest

SIS: $\mathrm{M}=15,10(\mathrm{SD}=14,55)$, a társas támogatás Éntól való távolsága: $\mathrm{M}=7,60(\mathrm{SD}=6,80), \mathrm{BDI}: \mathrm{M}=6,27(\mathrm{SD}=5,39)$, STAI-S: $\mathrm{M}=41,07(\mathrm{SD}=12,85)$
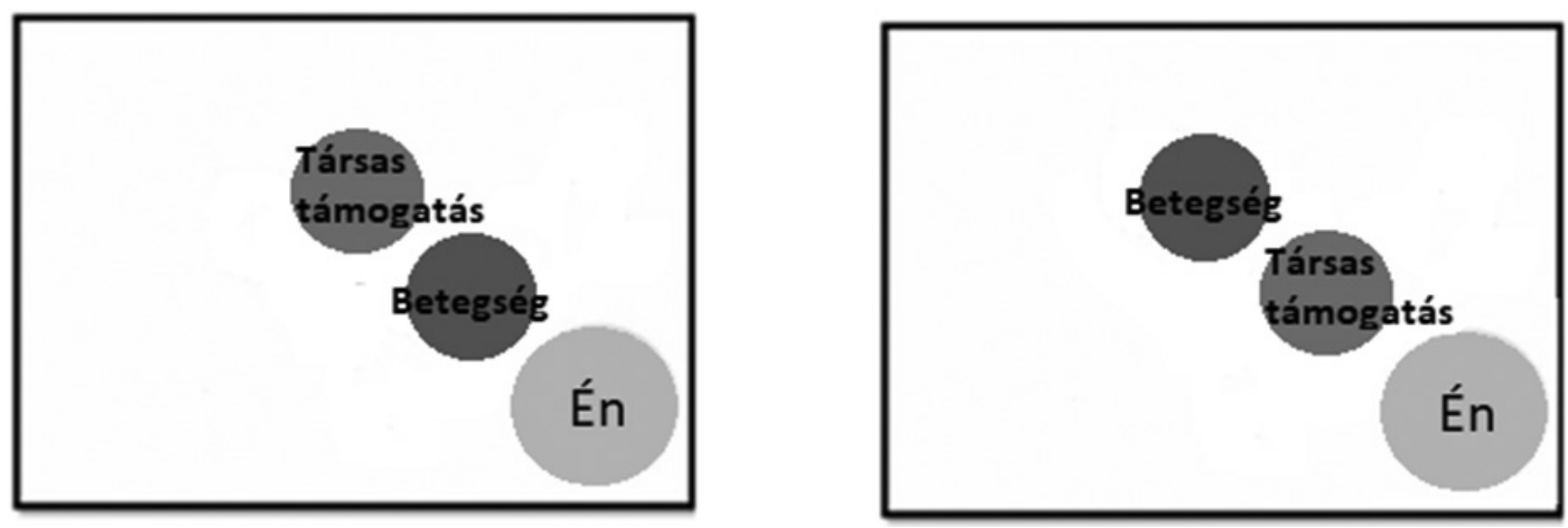

2. ábra A társas támogatást, a betegséget és az Ént szimbolizáló kör egymáshoz való viszonyával kapcsolatos eredmény demonstrálása BDI = Beck-féle Depresszió Kérdőív; $M$ = átlag; SD = szórás; SIS = Én-betegség távolság; STAI-S = a Spielberger-féle Vonás- és Állapotszorongás Kérdőív 'állapotszorongás' alskálája 
érzik szorosan közel magukhoz táras terük tagjait. Az eredmény összecseng azokkal a szakirodalmi adatokkal, melyek szerint a társas támogatás szerepet játszik a betegségkép kialakításában $[47,48]$, ami azért is fontos, mert vizsgálati eredmények alapján a betegséggel kapcsolatos nézetek és reprezentációk pedig számos, egészséggel kapcsolatos kimenetellel függnek össze $[49,50]$. Így tehát a társas támogatás közvetve, a betegségről alakított képre gyakorolt hatásával is befolyásolhatja a páciensek egészségi mutatóit.

A társas támogató tényezőknek a betegséghez és az Énhez viszonyított térbeli elhelyezkedése pedig további értékes információt nyújthat. Vizsgálati eredményeink szerint ugyanis azok a személyek, akik a betegséget rajzolták az Ént szimbolizáló körhöz közelebb, a társas támogatást pedig távolabb, szignifikánsan nagyobb szorongást és depressziószintet éltek meg, mint akik a 'betegség' kör és az 'Én' kör közé rajzoltak legalább egy társas támogató személyt. Ez az eredményünk mintegy vizuálisan jeleníti meg a stresszpufferelmélet lényegét, mely szerint a társas támogatás azáltal fejti ki jótékony hatását, hogy képes felfogni a stresszforrástól - mely jelen esetben a betegség - érkező káros hatásokat [12].

A rajzteszt alkalmas továbbá az észlelt szociális izoláció feltárására. A korábbi PRISM+ tesztekkel [40] szemben ugyanis ezen eljárásnál minden sugalmazás nélkül, a vizsgálati személyek döntik el, hogy a betegségen kívül milyen egyéb, számukra fontos, életterükben aktuálisan jelen levő tényezőt rajzolnak be. Így mérhető az egyén számára szubjektíve észlelt izoláció, mely fontos dimenzió, eredményeink szerint ugyanis azok a páciensek, akik aktuálisan nem jelenítették meg a társas támogatást életterükben, szignifikánsan magasabb szorongásszintet mutattak. Fontos megjegyezni, hogy súlyos betegség esetén a megélt izoláció sokszor nem azt jelenti, hogy a személy számára egyáltalán nem állnak rendelkezésre társas kapcsolatok. Sok esetben a betegségből adódó lelki folyamatok - például a figyelemnek a tünetekre való fokozott beszúkülése - miatt nem képesek mobilizálni ezeket a lehetséges erőforrásokat.

Azon eredményeink, melyek szerint a társas támogatás és a paciensek szorongásszintje között kapcsolat van, összefüggnek a szakirodalmi adatokkal [13-16], ami alátámasztja, hogy ez az újszerü vizuális mérőeszköz képes kimutatni azokat az összefüggéseket, melyeket a hoszszabb, időigényesebb, a betegektől több energiaráfordítást igénylő papír-ceruza tesztek tudnak. Mivel a teszt egyszerüen és gyorsan alkalmazható, akár újra és újra felvehető, detektálhatók akár a társas támogató térben bekövetkező változások (kapcsolatok gyengülése, erősödése).

Véleményünk szerint a PRISM-D teszt jól alkalmazható az észlelt társas támogatás jelenségének mérésére. Mint vizuális eszköz könnyen és gyorsan alkalmazható akár verbálisan nehezen kommunikáló betegeknél is. A személy aktuális életterébe berajzolt, társas támogatást szimbolizáló körök azonban csupán az aktuális percepci- óról árulkodnak, a támogatás mértékéről, potenciális elérhetőségéről, valamint a támogatás tényleges igénybevételéról nem kapunk információt. Az utóteszt tisztázó kérdése (mit jelent a páciens számára az adott tényező) ezekre részben választ adhat ugyan, de a tesztnek nem célja a fenti dimenziók részletes vizsgálata.

A teszt mint projektív eljárás lehetőséget biztosít az észlelt társas támogatás szubjektív, esetlegesen kevéssé tudatos elemeinek megjelenítésére. Segíthet tudatosítani azokat a társas eróforrásokat, melyeket a páciens korábban nem vagy csak kevéssé tudott hasznosítani, ami kiindulópontja lehet a terápiás munkában annak, hogy segítsünk a páciensnek segítséget kérni és igénybe venni a társas támogatást. A terápiás munka során a pszichológus segíthet továbbá abban is, hogy a betegek felismerjék, hogy a gyógyító szakemberek és a betegtársak is potenciális támogató személyekként vannak jelen aktuális életterükben. Segíthet a velük való kommunikáció beindításában, az igények és a kérések adekvát megfogalmazásában.

A PRISM-D további előnye, hogy nem csupán a társas támogatás szubjektíve érzékelt jelenlétét tudjuk felmérni, hanem annak a betegséghez való viszonyát is, elhelyezkedését az aktuális élettéren belül. Alkalmas a szubjektíve megélt szociális izoláció, illetve a társas kapcsolatok aktivizálási nehézségének kiszürésére. Hasznos lehet továbbá az intervenciós munka előkészítésében, információgyưjjtésben, a rapport kiépítésében, a terápiás munka megtervezésében vagy annak hatásának utánkövetésében is szomatikus betegek esetében.

Anyagi támogatás: A közlemény megírása, illetve a kapcsolódó kutatómunka anyagi támogatásban nem részesült.

Szerzôi munkamegosztás: S. Z.: A kutatás megtervezése, adatgyújtés, az adatok statisztikai értelmezése és a publikáció megírása. L. M.: A kutatás megtervezése, részvétel az adatgyüjtésben és az eredmények értelmezésében. Cs. M. a kutatási terv kidolgozásában, az eredmények értelmezésében és a kézirat megírásában nyújtott segítséget. A cikk végleges változatát valamennyi szerző elolvasta és jóváhagyta.

Érdekeltégek: A szerzőknek nincsenek érdekeltségeik.

\section{Köszönetnyilvánítás}

Köszönetet mondunk a kutatást segítő kollégáinknak, elsősorban $d r$ Kovács Péternek, az adatfelvételben nyújtott segítségért.

\section{Irodalom}

[1] Kaplan BH, Cassel JC, Gore S. Social support and health. Med Care 1997; 15(5 Suppl): 47-58.

[2] Lakey B, Drew JB. A social-cognitive perspective on social support. In: Pierce GR, Lakey B, Sarason IG, et al. (eds.) Source- 
book of social support and personality. Springer, Boston, MA, 1997; pp. 107-140.

[3] Holahan CJ, Moos RH, Holahan CK, et al. Social context, coping strategies, and depressive symptoms: an expanded model with cardiac patients. J Pers Soc Psychol. 1997; 72: 918-928.

[4] Turner-Cobb JM, Gore-Felton C, Marouf F, et al. Coping, social support, and attachment style as psychosocial correlates of adjustment in men and women with HIV/AIDS. J Behav Med. 2002; 25: 337-353

[5] Penninx BW, van Tilburg T, Boeke AJ, et al. Effects of social support and personal coping resources on depressive symptoms: different for various chronic diseases? Health Psychol. 1998; 17: $551-558$.

[6] Stone AA, Mezzacappa ES, Donatone BA, et al. Psychosocial stress and social support are associated with prostate-specific antigen levels in men: results from a community screening program. Health Psychol. 1999; 18: 482-486.

[7] Goodenow C, Reisine ST, Grady KE. Quality of social support and associated social and psychological functioning in women with rheumatoid arthritis. Health Psychol. 1990; 9: 266-284.

[8] Stefaniak TJ, Dziedziul J, Walerzak AM, et al. Pain intensity and perceived social support among patients with pancreatic tumors. J Pain Relief 2012; 1: 110.

[9] Krohne HW, Slangen KE. Influence of social support on adaptation to surgery. Health Psychol. 2005; 24: 101-105.

[10] Reblin M, Uchino BN. Social and emotional support and its implication for health. Curr Opin Psychiatry 2008; 21: 201-205.

[11] Uchino BN, Cacioppo JT, Kiecolt-Glaser JK. The relationship between social support and physiological processes: a review with emphasis on underlying mechanisms and implications for health. Psychol Bull. 1996; 119: 488-531.

[12] Cohen S, Wills TA. Stress, social support, and the buffering hypothesis. Psychol Bull. 1985; 98: 310-357.

[13] Procidano ME. The nature of perceived social support: findings of meta-analytic studies. In: Spielberger CD, Butcher JN. (eds.) Advances in personality assessment. Erlbaum, Hillsdale, NJ, 1992; pp. 1-26.

[14] Sarason BR, Sarason IG, Gurung RA. Close personal relationships and health outcomes: a key to the role of social support. In: Duck S. (ed.) Handbook of personal relationships: theory, research, and interventions. John Wiley \& Sons, New York, NY, 1997; pp. 547-573

[15] Lin N, Ye X, Ensel WM. Social support and depressed mood: a structural analysis. J Health Soc Behav. 1999; 40: 344-359.

[16] Lakey B, Cronin A. Low social support and major depression: research, theory and methodological issues. In: Dobson KS, Dozois DJ. (eds.) Risk factors for depression. Elsevier Academic Press, San Diego, CA, 2008; pp. 385-408.

[17] Bisschop MI, Kriegsman DM, Beekman AT, et al. Chronic diseases and depression: the modifying role of psychosocial resources. Soc Sci Med. 2004; 59: 721-733.

[18] Everson-Rose SA, Lewis TT. Psychosocial factors and cardiovascular disease. Annu Rev Public Health 2005; 26: 469-500.

[19] Patel SS, Peterson RA, Kimmel PL. The impact of social support on end-stage renal disease. Semin Dial. 2005; 18: 98-102.

[20] Molloy GJ, Johnston DW, Witham MD. Family caregiving and congestive heart failure: review and analysis. Eur J Heart Fail. 2005; 7: 592-603.

[21] Cardol M, Groenewegen PP, de Bakker DH, et al. Shared help seeking behaviour within families: a retrospective cohort study. BMJ 2005; 330: 882 .

[22] Brummet BH, Mark DB, Siegler IC, et al. Perceived social support as a predictor of mortality in coronary patients: effects of smoking, sedentary behaviour, and depressive symptoms. Psychosom Med. 2005; 67: 40-45.

[23] Stanton AL, Revenson TA, Tennen H. Health psychology: psychological adjustment to chronic disease. Annu Rev Psychol. 2007; 58: 565-592.
[24] Rokach A. Correlates of loneliness as perceived by the terminally ill. Curr Psychol. 2000; 19: 237-248.

[25] Spiegel D. Mind matters - Group therapy and survival in breast cancer. N Engl J Med. 2001; 345: 1767-1768.

[26] Arpin K, Fitch M, Browne BB, et al. Prevalence and correlates of family dysfunction and poor adjustment to chronic illness in specialty clinics. J Clin Epidemiol. 1990; 43: 373-383.

[27] Berkanovic E, Hurwicz ML. Rheumatoid arthritis and comorbidity. J Rheumatol. 1990; 17: 888-892.

[28] Vogt TM, Mullooly JP, Ernst D, et al. Social networks as predic tors of ischemic heart disease, cancer, stroke and hypertension: incidence, survival and mortality. J Clin Epidemiol. 1992; 45: 659-666.

[29] Fitzpatrick R, Newman S, Lamb R, et al. Social relationships and psychological well-being in rheumatoid arthritis. Soc Sci Med. 1988; 27: 399-403.

[30] Cacioppo JT, Hawkley LC. Social isolation and health, with an emphasis on underlying mechanisms. Perspect Biol Med. 2003; 46(3 Suppl): S39-S52.

[31] Uchino BN. (ed.) Social support and physical health: Understanding the health consequences of our relationships. Yale University Press, New Haven, CT, 2004.

[32] Barrera M. Social support research in community psychology. In: Rappaport J, Seidman E. (eds.) Handbook of community psychology. Kluwer Academic/Plenum, New York, NY, 2000; pp. 215-245.

[33] Hartmann M, Bäzner E, Wild B, et al. Effects of interventions involving the family in the treatment of adult patients with chronic physical diseases: a meta-analysis. Psychother Psychosom. 2010; 79: 136-148.

[34] Martire LM, Schulz R, Helgeson VS, et al. Review and metaanalysis of couple-oriented interventions for chronic illness. Ann Behav Med. 2010; 40: 325-342.

[35] Havancsák R, Pócza-Véger P, Csabai M. The PRISM-D drawing test in the examination and treatment of hospital patients. In: Csabai M, Pintér JN. (eds.) Psychology in healing: Phenomenological, art psychological and body representation centered approaches. [A PRISM-D rajzteszt kórházi betegek vizsgálatában és kezelésében. In: Csabai M, Pintér JN. (szerk.) Pszichológia a gyógyításban: Fenomenológiai, múvészetpszichológiai és testkép-központú megközelítések.] Oriold és Társai Kiadó, Budapest, 2013; pp. 83-107. [Hungarian]

[36] Sándor Z, Látos M, Pócza-Véger P, et al. The drawing version of the pictorial representation of illness and self measure. Psychol Health 2020 Feb 17. Doi: 10.1080/08870446.2019.1707825. [Online ahead of print]

[37] Sándor Z, Csabai M. Application of the PRISM-D drawing test to the complex examination of cancer-related emotional and cognitive representations. [A PRISM-D rajzteszt alkalmazása a daganatos betegséggel összefüggő érzelmi és kognitív reprezentációk komplex vizsgálatára]. Orv Hetil. 2018; 159: 2021-2030. [Hungarian]

[38] Büchi S, Sensky T. PRISM: Pictorial Representation of Illness and Self Measure. A brief nonverbal measure of illness impact and therapeutic aid in psychosomatic medicine. Psychosomatics 1999; 40: 314-320.

[39] Reimus JL, Vingerhoets AJ, Soons PH, et al. Suffering in psoriasis patients: its relation with illness severity and subjective wellbeing. Int J Dermatol. 2007; 46: 1042-1045.

[40] Büchi S, Sensky T, Sharpe L, et al. Graphic representation of illness: a novel method of measuring patients' perceptions of the impact of illness. Psychother Psychosom. 1998; 67: 222-225.

[41] Stefaniak TJ, Dziedziul J, Walerzak AM, et al. Pain intensity and perceived social support among patients with pancreatic tumors. J Pain Relief 2012; 1: 110. Doi: 10.4172/2167-0846.1000110.

[42] Spielberger CD, Gorsuch RL, Lushene RE. Manual for the statetrait anxiety inventory. Consulting Psychologists Press, Palo Alto, CA, 1970. 
[43] Sipos K, Sipos M. The development and validation of the Hungarian form of the STAI. In: Spielberger CD, Diaz-Guerrero R. (eds.) Cross-Cultural Anxiety. Hemisphere Publishing Corporation, Washington-London, 1978; pp. 51-61.

[44] Beck AT, Ward CH, Mendelson M, et al. An inventory for measuring depression. Arch Gen Psychiatry 1960; 4: 561-571.

[45] Richter P, Werner J, Heerlein A, et al. On the validity of the Beck Depression Inventory. A review. Psychopathology 1998; 31: 160-168.

[46] Rózsa S, Szádóczky E, Füredi J. Characteristics of the Beck Depression Scale in Hungarian Sample. [A Beck Depresszió Kérdőív rövidített változatának jellemzői hazai mintán.] Psychiatr Hung. 2001; 16: 384-402. [Hungarian]

[47] Guzman SJ, Nicassio PM. The contribution of negative and positive illness schemas to depression in patients with end-stage renal disease. J Behav Med. 2003; 26: 517-534.
[48] Benyamini Y, Medalion B, Garfinkel D. Patient and spouse perceptions of the patient's heart disease and their associations with received and provided social support and undermining. Psychol Health 2007; 22: 765-785.

[49] Hagger MS, Orbell S. A meta-analytic review of the commonsense model of illness representations. Psychol Health 2003; 18: 141-184.

[50] Petrie KJ, Jago LA, Devcich DA. A role of illness perceptions in patients with medical conditions. Curr Opin Psychiatry 2007; 20: 163-167.

(Sándor Zita,

Gyula, Tomcsányi u. 11., 5700 e-mail: sandorzita89@gmail.com)

\section{"Sat magna usura est pro beneficio memoria." (A jóság fejében megfelelő kamat az emlékezet.)}

A cikk a Creative Commons Attribution 4.0 International License (https://creativecommons.org/licenses/by/4.0/) feltételei szerint publikált Open Access közlemény, melynek szellemében a cikk bármilyen médiumban szabadon felhasználható, megosztható és újraközölhető, feltéve, hogy az eredeti szerző és a közlés helye, illetve a CC License linkje és az esetlegesen végrehajtott módositások feltüntetésre kerülnek. (SID_1) 